\title{
CHANGES IN ANTHROPONYMIC PREFERECES OF ODESA REGION INHABITANTS (UKRAINE) IN TIME
}

\section{Braychenko S. L.}

\section{INTRODUCTION}

Personal names have aroused people's interest long. And, despite the fact that they are one of the oldest interlayers of our language and were the subject of interest of ancient Greek and Roman scholars, in our time as a special anthroponymic class is insufficiently studied.

Recently, anthroponymic issues have significantly expanded, considerable experience in collecting and studying data on proper names has been accumulated and generalized, new areas of research have been outlined, and original methods for studying personal names have been developed. All anthroponymic classes have now become the subject of special studies.

In a relatively short period of time, Ukrainian anthroponymy has achieved success: many fundamental monographic studies of such linguists as P.P. Chuchka, L.L. Humetska, M.L. Khudash, Y.K. Redko, I.D. Sukhomlyn, R. J. Kestra, L.T. Masenko, A.P. Koval, M.O. Demchuk, I.P. Glinsky, L.O. Beley and others.

In linguistic researches a number of researches on anthroponymy of the mentioned authors, and also I.I. Kovalik, I.M. Zheleznyak, S.P. Bevzenko, V.V. Nimchuk, O.Y. Karpenko, G.P. Pivtorak, M.V. Karpenko, G.F. Shila, L.V. Krakalii, O.D. Nedilka, G.E. Buchko and others are published.

These works initiated great work that requires the collection, systematization and study of a huge and diverse material containing modern anthroponymicon.

Recently, in the studies of anthroponymists, the sociolinguistic aspect of the study of personal names has become increasingly clear, which requires special research. Many of their works are devoted to the analysis of actually used names that a person officially receives at birth. But since anthroponymy is a complex social phenomenon, it requires other approaches to their study. We study not the names we actually use, but the ones that people like and subjectively rate as the best.

The purpose of this work is to analyze names according to the degree of their social evaluation, identifying changes in anthroponymic preferences over time, and to compare the results of studying the temporal real dynamics of names with the modern attitude to names. 
The research was performed within the framework of the topic "Actual issues of Ukrainian word formation and onomastics", which is being developed by the Department of Ukrainian Language of I.I. Mechnikov Odesa University.

The object of research is popular names in the composition of modern anthroponymic preferences. Nouns from the city of Odesa, Odesa region and adjacent regions were used for comparison.

The source of factual material was the results of sociolinguistic practice of students of the philological faculty of I.I. Mechnikov Odesa University. Each participant in the practice collected data from 50 respondents on the 10 names they like best.

To solve the tasks set in the study, complex methodological techniques are used, which correspond to the sociolinguistic and specifically onomastic, anthroponymic aspect: 1) descriptive, which allowed on the basis of analysis of the frequency of names to identify six groups of anthroponyms; 2) the method of chronological sections - all names are divided into groups depending on the age of birth of the recipients, as a result of which six age sections were identified; 3 ) the comparative method allowed to compare the repertoire of anthroponymic preferences with the real noun and the components of the specific and common in the sympathies of representatives of different age groups. ${ }^{1}$

The novelty of the obtained results is that for the first time personal names are considered through the prism of preferences and the collected material is compared with the results of researchers of real name usage.

The theoretical and practical value of the work is that the materials and results of the study will be useful in developing theoretical and practical problems of onomastics. The obtained results will be useful in research in lexicology, in covering such issues as language and society, the interaction of languages. The collected materials are of interest to compilers of dictionaries of people's proper names and used in the practice of naming.

Summarizing the data of all age groups, we found that the views of names of respondents of different ages changed, demonstrating four types of development (Dynamics of onyms are considered in conjunction with all their unofficial variants recorded in our materials):

1. Anthroponyms, sympathy for which increases with age.

2. Names whose interest declines in the first age sections compared to previous ones.

3. Onyms views on which coincide with I and VI age sections, but on the middle these names: a) strengthen the position; b) lose their appeal.

1 Брайченко С.Л. Антропонімічні уподобання мешканців Одеської області України: лінгвістичний аналіз: Автореф.дис. ... канд. філол. наук. Одеса, 1999. С. 2. 
4. Anthroponyms, which are determined by the stability in relation to themselves throughout all sections.

\section{Male names}

Male names, the origin of which dates back to antiquity, attract the attention of many researchers. Since in the past their composition far exceeded the repertoire of female names, "Ukrainian anthroponymy is studied almost exclusively at the level of male names"2 in the works of such linguists as R.J. Kestra, M.L. Khudash, I.D. Sukhomlyn, V.O. Kolesnyk and others.

The system of male names in its development has come a long and interesting way, actively responding to all the changes that have taken place in society during this time. From the end of the XX century, i.e after the adoption of Christianity, during the rite of baptism in the church, the child received the name from the saints. Christian names were given regardless of the parents' wishes in honor of the saint, whose memory was celebrated on the day the child was born. With Christianization, Ukraine embarked on a broad path of progress sanctified by the ideals of Christian humanism. The ideals of Christianity, Christian rituals led to profound changes in the spiritual life of our ancestors. The coercive power of pagan names was incompatible with Christian doctrine. Therefore, one of the first radical reforms underwent a repertoire of names.

And since the end of the XVI century there is a significant replenishment of names, which is closely related to the development of life and culture of our people.

Over a thousand years of history, Christian names have become an integral part of Ukrainian life. That is why "anthroponymy is a treasure trove of historical and cultural heritage, the subject of a special study of the general history of the people"3

Attitudes toward names have changed over time. Evidence of this is the composition of modern anthroponymic preferences, which is clearly different from the noun in the past. 568 male names are recorded in our materials, 301 of them are different names, more precisely, invariants; the rest are hypocoristics and diminutives and uncodified forms of names. All of them are differently liked by members of six age groups; some anthroponymic preferences become archaic relatively quickly, while others become more popular. The dynamics of male names that have been part of the popular are presented in table 1 .

${ }^{2}$ Сенів М.І. До іторії адаптації жіночих календарних імен в українській мові XIV - поч. XIX ст. Мовознавство. 1982. С. 72.

3 Кестра Р.Й. Українська антропонімія XVI ст. Чоловічі іменування. Київ : Наук.думка, 1984. С. 3. 
Table 1

Male names registered in the popular group. Official names in combination with unofficial ones. (with rank number)

\begin{tabular}{|c|c|c|c|c|c|c|c|}
\hline № & Names & $\begin{array}{c}\text { I } \\
\text { section }\end{array}$ & $\begin{array}{c}\text { II } \\
\text { section }\end{array}$ & $\begin{array}{c}\text { III } \\
\text { section }\end{array}$ & $\begin{array}{c}\text { IV } \\
\text { section }\end{array}$ & $\begin{array}{c}\text { V } \\
\text { section }\end{array}$ & $\begin{array}{c}\text { VI } \\
\text { section }\end{array}$ \\
\hline 1 & Olexander & 2 & 1 & 1 & 1 & 1 & 1 \\
\hline 2 & Sergiy & 5 & 4 & 2 & 2 & 2 & 2 \\
\hline 3 & Oleh & 12 & 6 & 4 & 3 & 3 & 3 \\
\hline 4 & Mykola & 3 & 2 & 3 & 4 & 5 & 6 \\
\hline 5 & Volodymyr & 6 & 7 & 5 & 5 & 4 & 4 \\
\hline 6 & Ivan & 1 & 3 & 6 & 8 & 9 & 15 \\
\hline 7 & Ihor & 17 & 11 & 11 & 7 & 6 & 5 \\
\hline 8 & Victor & 11 & 16 & 9 & 6 & 8 & 6 \\
\hline 9 & Andriy & 9 & 8 & 10 & 9 & 10 & 9 \\
\hline 10 & Vasyl & 4 & 5 & 8 & 10 & 13 & 14 \\
\hline 11 & Yuriy & 16 & 9 & 7 & 11 & 11 & 7 \\
\hline 12 & Dmytro & 10 & 14 & 14 & 12 & 7 & 11 \\
\hline 13 & Mykhailo & 7 & 10 & 12 & 13 & 12 & 19 \\
\hline 14 & Oleksiy & 15 & 15 & 13 & 14 & 14 & 10 \\
\hline 15 & Anatoly & 13 & 13 & 16 & 15 & 15 & 18 \\
\hline 16 & Petro & 8 & 12 & 15 & 16 & 19 & 28 \\
\hline 17 & Vitaliy & 25 & 17 & 19 & 18 & 16 & 12 \\
\hline 18 & Valery & 26 & 20 & 17 & 17 & 17 & 17 \\
\hline 19 & Ruslan & + & 32 & 25 & 19 & 21 & 13 \\
\hline 20 & Pavlo & 18 & 23 & 18 & 20 & 18 & 31 \\
\hline 21 & Maxim & 23 & 18 & 22 & 22 & 20 & 21 \\
\hline 22 & Evhen & 24 & 22 & 21 & 25 & 24 & 23 \\
\hline 23 & Vadim & + & 30 & 27 & 23 & 22 & 16 \\
\hline 24 & Roman & 28 & 27 & 28 & 21 & 23 & 24 \\
\hline 25 & Gregoriy & 14 & 19 & 20 & 26 & 32 & 32 \\
\hline 26 & Vyacheslav & 22 & 31 & 25 & 24 & 26 & 20 \\
\hline 27 & Kostyantyn & + & 28 & 30 & 28 & 25 & 22 \\
\hline 28 & Stepan & 20 & 21 & 23 & 27 & 32 & + \\
\hline 29 & Boris & 27 & 25 & 24 & 30 & 31 & 30 \\
\hline 30 & Leonid & 21 & 24 & 29 & 29 & 30 & + \\
\hline 31 & Denis & + & 29 & 32 & 31 & 27 & 25 \\
\hline 32 & Gennady & + & 33 & 33 & 32 & 28 & 26 \\
\hline 33 & Valentine & + & + & 34 & 33 & 29 & 27 \\
\hline 34 & Fedir & 19 & 26 & 31 & + & + & + \\
\hline 35 & Arthur & + & + & + & + & 34 & 29 \\
\hline 36 & Bohdan & 30 & + & + & + & + & + \\
\hline 37 & Taras & 29 & + & + & + & + & + \\
\hline & presentam & & + & & & & 13 \\
\hline
\end{tabular}

+ present among anthroponymic preferences, but outside of popular names. 
The first type of development (anthroponyms, sympathy for which increases with the age of informants) is shown by the names Sergiy (in the first age section the popularity is 4.6 , and in the 6th $-5.5 \%$ ), which was used much less often in naming; Scandinavian Oleh (4.4-4.9\%) and Ihor (3.5-4.1\%), who was glorified by the powerful prince of Kievan Rus; Olexander (3.5-4.0\%), the popularity of which is facilitated by his existence in numerous vernacular versions, in the reference literature recorded as many as 126 of his informal forms; ${ }^{4}$ ancient Christian Oleksiy (2.1-2.3\%); melodious Vitaliy (1.8-2.8\%), which is "borrowed from Greek through the Old Slavonic language along with the adoption of Christianity, derived from the Latin word "vita" - life, it was like a kind of mascot; calling his son that way, the parents wished him long life" " Valery (1.6-1.9\%), which "in the 60s was attractive to parents thanks to famous athletes Valery Brumel and Valery Lobanovsky"; ${ }^{\circ}$ Ruslan (1.7-2.8\%) - one of the most common names of all the Turkic peoples of the Middle Ages, which the church once despised because of its pagan origin; sonorous and beautiful Kostyantyn (0.6-0.8\%); Denis (0.9-1.4\%), which belongs to the oldest European names, it is found in the Homeric epoch in the form of Dionysus - the name of the ancient Greek god of wine and merriment; old calendar Gennady (0.8-1.0\%); Ancient Roman Valentine (0.9-1.1\%), which gained popularity among the Eastern Slavs recently, around the beginning of the XIX century, according to I. Glinsky, this name "brought us French sentimental novels, including the novel by Georges Sand "Valentine"; melodious, etymologically transparent Slavic autochthonous Vadim (1.2-1.6\%), the meaning of which has not been unanimously interpreted. "Some consider it Persian, but most researchers tend to deduce from the Old Russian verb vaditi - to argue, to provoke disagreement. It may be an abbreviated form of the Slavic Volodymyr"

The most interesting fate was in the name of Arthur (0.7-1.15), which appeared in the popular only in the V century.

The analysis of such onyms with progressive dynamics gives a clear idea of the clear heterogeneity of the attitude of the elderly and the younger generation. Among the preferences of informants of recent ages, there is a tendency to admire the relatively new names, the spread of which is facilitated by popular works of fiction, cinema.

${ }^{4}$ Тихонов А.Н. Словарь русских личных имен. Москва : Школа-пресс, 1995. С. 30.

5 Півторак Г.П. 3 історії власних імен людей: Віталій, Мирон, Світлана. Культура слова. Київ: Наук. думка. 1985. Вип. 28. С. 53.

${ }^{6}$ Півторак Г.П. 3 історії власних імен людей: Валентин, Валентина, Валерій. Культура слова. Київ : Наук. думка. 1985. Вип. 29. С. 50.

${ }^{7}$ Глинський І. Твоє ім'я - твій друг. Київ : Веселка, 1985. С. 109.

${ }^{8}$ Скрипник Л.Г., Дзятківська Н.П .Власні імена людей: Словник-довідник / За ред. В.М. Русанівського. Київ: Наукова думка, 1996. С. 44. 
The repertoire of names that position the second type of development, interest in which decreases in the first age sections compared to the previous ones, contains the following anthroponyms: Ivan (3.4\%-2.0\%), which regardless of taste was the most common in ancient times, the reason high popularity was manifested in frequent repetition in the holidays, Researchers counted 62 Ivans a year, in the full holidays Ivan is mentioned almost 170 times, nowadays this onym finds a lot of supporters not only among Ukrainians but also the most popular among the peoples of Europe. variants (John, Jean, Ian, Juan) it is widely used in other countries. In all East Slavic peoples, the name Ivan is a very popular protagonist of folk songs and fairy tales. According to researchers, it became popular first in princely and royal families, and then among urban and rural commoners. Earlier in the village, 16-25\% of all peasants were named Ivan - one in three was Ivan. Due to its widespread use, this token has acquired the ability to be used with various additional meanings, acting in the form of "secondary, associative-figurative naming of people. There are also cases of "figurative" use of the name Ivan, which, in our opinion, contributed to the reduction of his activity according to the age of informants in our materials; Mykola (3.2-2.5\%), which in various forms is very common among all Slavic and many European nations. Such a high interest in this name is due to the fact that it often occurs in Ukrainian folklore (in songs and kolomyykas), in the works of Ukrainian writers; Vasyl (2.7-1.8), who has lived in our country for almost a millennium, and the reputation of being popular by this name has been preserved from ancient times to the present; Mykhailo (2.2-1.5\%) is an ancient traditional name, "which one can be proud of, whose honor there is someone to protect, because it belonged to famous people - Lomonosov, Kotsyubynsky, Maksymovych, composer Hlyntsi and actor Shchepkin"; 9 Petro (2.0-1.0\%) - "a name-symbol, because, as we know, Petro was destined to become the rock on which Christ founded the Christian church" ${ }^{10}$, this name is widely sung in Ukrainian folk songs, and is often used in the works of I. Kotlyarevsky, T. Shechenko, M. Kotsyubynsky and other Ukrainian writers; very common in the Ukrainian language old calendar names Pavlo (1.4-0.8\%), Gregoriy (1.2-0.7\%), Stepan (1.2-0.5\%), Leonid $(0.9-0.7 \%)$, Fedor $(0.8-0.3 \%)$. Significantly weakened their positions since the second century, leaving the boundaries of popular, names and Taras $(0.5-0.2 \%)$, which from Shevchenko has become incredibly popular, purely national, and Bohdan $(0.8-0.7 \%)$ - naming the glorious son of the Ukrainian people Bohdan Khmelnytsky. M.O. Demchuk states that "the name Bogdan is very popular in the life of Ukrainians in the

9 Коваль А.П. Практична стилістика української мови. Київ : Вища школа, 1987. С. 121.

${ }^{10}$ Белей Л.О. Ім'я дитини в українській родині. Ужгород : Просвіта,1993. С. 14. 
fourteenth - eighteenth centuries"11 An interesting history of the etymologically transparent Slavic name Bohdan is given by A.P. Koval: except for a few handwritten calendars). But the Catholic Church introduced this name in its calendar. That is why the name Bohdan is especially widespread in the western lands of Ukraine" 12

The contingent of onyms representing the third type of development, where the views of recipients in the I and VI age sections coincide, but in the middle these names strengthen their positions, contains anthroponyms Andriy (3.3-3.4\% with the peak of popularity in the II and III age sections $3.8 \%$ ) - a beautiful name that the East Slavic languages inherited from Old Russian, where it was borrowed through the Church Slavonic mediation of the Greek language; Victor (2.8-2.8\%) acquires the highest degree of popularity in the second cut $-3.0 \%$ - a name born in a distant Roman land; Yuriy (2.3-2.2\%, the most attractive for respondents of the third age group $2.8 \%$ ) - a folk form of the canonized name Heorhiy, such a form has long remained purely princely, it became independent only in 1917. Boris $(0.9-1.0 \%$, the largest number of supporters was found in the second age group $-1.3 \%$ ) - Slavic indigenous name. Name Boris in linguistic literature is mostly derived from the Bulgarian king Bogoris, baptized in 864, which is etymologically related to the Mongolian Borori "small"13 G.G. Dobromodov considers this name as Slavic, more precisely Old Russian borrowing from Turkic, deriving its etymology from the Bulgarian name Barysh (<Barys). However, most researchers adhere to the opinion expressed by O. Sobolevsky that this name is of Slavic origin, formed from the personal name-composite Borislav.

The fourth type of development is demonstrated by anthroponyms, which are determined by the stability in relation to themselves throughout all sections. These are such names as Volodymyr (2.9-3.0\%) - an extremely popular and pleasant name that has a high authority for a long time, it entered the saints as the name of Prince of Volodymyr Kiev (960-1015), who baptized, and for this he was recognized as an equal apostolic saint. "For several centuries, this name remained princely. It spread to all strata of society in the 19th century" 14; Dmytro $(2.1-2.1 \%)$ is a name that "East Slavic languages inherited from ancient Greek. It comes from the name of the Greek goddess of agriculture Demeter. The ancient Greeks greatly valued this goddess - the sister of the almighty Zeus, sung in one of the

11 Демчук М.О. Слов'янські автохтонні особові власні імена в побуті українців XIV - XVII ст. / М.О. Демчук. Київ: Наук.думка,1988. С. 39.

${ }^{12}$ Коваль А.П. Життя і пригоди імені. Київ: Вища школа,1988. С. 90.

13 Демчук М.О. Слов'янські автохтонні особові власні імена в побуті українців XIV-XVII ст. Київ: Наукова думка,1988. С. 85.

${ }^{14}$ Никонов В.А. Ищем имя. Москва : Сов.Россия, 1998. С. 104. 
hymns of Homer"15; old traditional names Maxim (1.7-1.7\%), Anatoly (1.6-1.5\%), Roman (1.3-1.4\%), Evhen (0.9-1.0\%) and Old Russian Vyacheslav $(0.7-0.8 \%)$.

If we consider the repertoire of anthroponymic preferences of the first ten most popular names of the last age in comparison with the modern picture of naming, we can see that the attitude to names is relatively stable. For research we use materials of L.P. Zaychikova - in Odesa, D.O. Zhmurko in Izmail, O.Y. Kasim - in Odesa region. (See table 2)

Table 2

Modern anthroponymic preferences and real naming (male names)

\begin{tabular}{|c|c|c|c|c|}
\hline \multirow{2}{*}{ № } & \multirow{2}{*}{$\begin{array}{c}\text { Favorite names on } \\
\text { the VI age section }\end{array}$} & Odesa & Odesa region & Izmail \\
\cline { 3 - 5 } & Olexander & Sergiy & Olexander & Olexander \\
\hline 1 & Sergiy & Olexander & Sergiy & Sergiy \\
\hline 2 & Oleh & Andriy & Volodymyr & Volodymyr \\
\hline 3 & Volodymyr & Oleh & Mykola & Ihor \\
\hline 4 & Ihor & Ihor & Victor & Victor \\
\hline 5 & Victor & Dmytro & Yuriy & Yuriy \\
\hline 6 & Yuriy & Yuriy & Valery & Olexiy \\
\hline 7 & Mykola & Olexiy & Vasyl & Andriy \\
\hline 8 & Andriy & Volodymyr & Oleh & Vitaliy \\
\hline 9 & Olexiy & Evhen & Anatoly & Oleh \\
\hline 10 & & & & \\
\hline
\end{tabular}

As you can see, views on popular names are almost unchanged. Evidence of this is the presence in the above materials of 5 common names Olexander, Sergiy, Oleh, Volodymyr, Yuriy, who seek high positions in other regions of Ukraine, in particular in Kherson ${ }^{16}$ and Mykolayiv region. ${ }^{17}$

Anthroponyms Ivan and Mykhailo (except for the second section), which during the twentieth century showed high activity in the real name of Uzhhorod $^{18}$ did not leave the limits of the frequency ten; from the 4th to the 9th section, the names Vasyl, Viktor, Yuriy are also registered here.

Obviously, in the future they will continue to exist at a similar level and continue to lead the frequency lists of newborn names.

Indicators of table 2 also allow us to predict the progressive dynamics of the names Ihor, Victor, Andriy, Olexiy, Mykola.

15 Півторак Г.П. 3 історії власних імен людей: Григорій, Дмитро, Святослав, Лідія, Ніла, Юлія. Українська мова та література в школі. Київ: Наукова думка. 1986. № 10. С. 64.

${ }^{16}$ Петрова Р.В. Динамика мужского именника г. Херсона. VI Респ. ономаст. Конференція: Тези доп. І повід. Одеса, 1990. Ч. 2. С. 74.

17 Братушенко Т.Д. Антропоніми Правобережного Побужжя. Украӥнське мовознавство. Київ : Вища школа. 1980. Вип.8. С. 101.

${ }^{18}$ Шоля І.С.. Динаміка частотного десятка чоловічих імен Ужгорода впродовж ХХ ст. Записки з ономастики: зб. наук. пр. Одеса,2017. Вип. 20. С. 264. 
If we compare the composition of the last age sections of anthroponymic sympathies and the real noun ${ }^{19}$, it can be noted that views on names level off over time: the attitude to most names over the 20-year period has not changed. This applies to the names of Sergiy, Olexander, Andriy, Volodymyr , Vadim, Valery, Anatoly, Vyacheslav, Kostyantyn, Vladislav, Leonid, Heorhiy, Eduard, Stanislav.

Over the years, interest in the anthroponyms Eugene and Dmitry has changed markedly. The names Vitaliy, Ruslan, Artem, Arkadiy, and Yaroslav significantly strengthened their positions.

Despite the fact that in our materials the sympathy for such names as Ivan, Vasyl, Mykola, Mykhailo, Pavlo, Petro, Fedir, Taras, Stepan decreases with the decrease of the age of the respondents, in modern real name they are quite common.

Preservation of these very popular long-standing names among frequencies nowadays testifies to their potential power, high reserve of their durability. Based on this. We can talk about the frequency of use of the above anthroponyms in the future.

\section{Female names}

In works on historical onomastics, "less attention is paid to the forms of women's names, because they, having actually no legal rights in the past, are much less often mentioned in the monuments of business writing of the XIXIV centuries" ${ }^{20}$ The social disenfranchisement of women during this period was reflected in the official script, and the ways of naming her were disordered and therefore not monotonous.

For historical reasons, female names have long occupied a secondary place in church calendars. The saints had four times fewer female names than male ones.

Female names have not remained outside the scope of scientific study yet, becoming the subject of special research in the works of famous linguists.

The system of female names has been actively expanding over time, and recently the women's repertoire contains a large group of beautiful, melodious names, exceeding the composition of men.

Evidence of this is an interesting and diverse range of female names offered by modern representatives of different generations, which contains 654 names that are differently liked by our respondents.

The dynamics of female names, which were part of the popular, are presented in table 3 .

19 Зайчикова Л.П. Русский именник г. Одессы : дис. ... канд. филол. наук. Приложение. Одесса, 1986. С. 36-38.

${ }^{20}$ Суперанская А.В. Имя и эпоха. Историческая ономастика: Сб cm. Москва : Наука, 1977. С. 15. 
Table 3

Female names registered in the popular group. Official names combined with unofficial ones. (with rank number)

\begin{tabular}{|c|c|c|c|c|c|c|c|}
\hline № & Names & $\begin{array}{c}\text { I } \\
\text { section }\end{array}$ & $\begin{array}{c}\text { II } \\
\text { section }\end{array}$ & $\begin{array}{c}\text { III } \\
\text { section }\end{array}$ & $\begin{array}{c}\text { IV } \\
\text { section }\end{array}$ & $\begin{array}{c}\mathbf{V} \\
\text { section }\end{array}$ & $\begin{array}{c}\text { VI } \\
\text { section } \\
\end{array}$ \\
\hline 1 & Olena & 3 & 2 & 2 & 3 & 2 & 2 \\
\hline 2 & Olha & 2 & 1 & 1 & 1 & 1 & 1 \\
\hline 3 & Iryna & 8 & 4 & 3 & 2 & 4 & 4 \\
\hline 4 & Maria & 1 & 3 & 5 & 7 & 8 & 6 \\
\hline 5 & Natalia & 9 & 7 & 6 & 4 & 3 & 3 \\
\hline 6 & Tetiana & 5 & 9 & 8 & 5 & 9 & 5 \\
\hline 7 & Liudmila & 7 & 8 & 4 & 9 & 6 & 7 \\
\hline 8 & Oksana & 13 & 5 & 7 & 8 & 5 & 9 \\
\hline 9 & Svitlana & 15 & 12 & 9 & 6 & 7 & 8 \\
\hline 10 & Kateryna & 6 & 6 & 11 & 11 & 10 & 11 \\
\hline 11 & Ganna & 4 & 11 & 12 & 12 & 14 & 12 \\
\hline 12 & Valentina & 11 & 13 & 13 & 10 & 12 & 13 \\
\hline 13 & Halyna & 12 & 10 & 10 & 13 & 13 & 18 \\
\hline 14 & Nadiya & 14 & 14 & 14 & 14 & 11 & 17 \\
\hline 15 & Victoria & 28 & 20 & 16 & 15 & 15 & 10 \\
\hline 16 & Liubov & 10 & 15 & 15 & 17 & 19 & 19 \\
\hline 17 & Julia & 27 & 18 & 17 & 16 & 17 & 14 \\
\hline 18 & Inna & + & 22 & 20 & 18 & 16 & 15 \\
\hline 19 & Marina & 20 & 17 & 19 & 19 & 20 & 16 \\
\hline 20 & Larisa & 25 & 24 & 18 & 21 & 22 & 21 \\
\hline 21 & Alla & + & 23 & 24 & 20 & 18 & 20 \\
\hline 22 & Anastasia & 16 & 21 & 21 & 23 & 21 & 23 \\
\hline 23 & Nina & 17 & 16 & 22 & 22 & 23 & 26 \\
\hline 24 & Vira & 18 & 19 & 23 & 24 & 25 & 24 \\
\hline 25 & Lidia & 19 & 25 & 25 & 26 & 27 & 28 \\
\hline 26 & Olexandra & 22 & 26 & 26 & 25 & 26 & 27 \\
\hline 27 & Liliya & + & + & + & 28 & 24 & 22 \\
\hline 28 & Evgenia & 21 & + & 27 & 29 & + & + \\
\hline 29 & Zinaida & 23 & + & 28 & 27 & + & + \\
\hline 30 & Raisa & 30 & + & 29 & + & 28 & + \\
\hline 31 & Antonina & + & + & + & + & 29 & + \\
\hline 32 & Tamara & + & 27 & + & + & + & + \\
\hline 33 & Angela & + & + & + & + & + & 25 \\
\hline 34 & Sofia & 29 & + & + & + & + & + \\
\hline 35 & Daria & 24 & + & + & + & + & + \\
\hline 36 & Valeria & + & + & + & + & + & 29 \\
\hline 37 & Evdokia & 26 & + & + & + & + & + \\
\hline
\end{tabular}

$+i$ s present among anthroponymic preferences, but outside of popular names. 
The first of these types of development of anthroponymic sympathies, characterized by an increase in attractiveness with decreasing age of recipients, shows a larger number of female names (about 50\%) compared to the male range. These are such ancient church onyms as "peaceful, calm" (Gr.) Iryna (3.0-3.1\%); Oksana (3.6-3.7\%) is a former Ukrainian vernacular version of the church Xenia, which came to us during the Kievan Rus from Greece through Byzantium, now this name has gained official status and is one of the most popular Ukrainian names, which is often occurs in ancient and modern folk songs and thoughts, in fiction; "Silent, quiet, calm" (gr.) Tetiana (2.4-2.7\%) - a name that first existed in the aristocratic environment, but in the late eighteenth - early. XX century it began to be used in peasant families; Victoria $(1.4-2.0 \%)$ - the name of the ancient Roman goddess of victory; Marina $(1.8-2.1 \%)$ - a beautiful name of the traditional fund, Larisa $(1.5-1.7 \%)$ - a name that has gained popularity relatively recently; and Slavic autochthonous: Svitlana $(2.6-3.0 \%)$ - an anthroponym, which "in foreign Slavs is found in the Sopot noun, and in the eastern known since the times of Kievan Rus, when along with Christian names borrowed from Byzantium , used and local, originally Slavic"21; Liudmila (2.3-2.4\%) is an attractive and beautiful ancient Slavic name, which has its roots deep in its native language. During the first five sections, views on names with a distinctly foreign color Angela $(0.7-1.1 \%)$ and Valeria $(0.5-0.9 \%)$ were formed. Melodiousness, ease in pronunciation of tokens Natalia (2.6-3.1\%) - female form of unproductive male name Nataliy; Julia (0.9-1.1\%), Liliya (0.6-1.1\%) - appellate formation by the name of the flower; Anastasia (0.7-0.9\%) and Antonina (0.4-0.5) - female forms of male names Anastas and Anton; the identity of the full and short forms contributed to the increase of authority among the recipients of the younger age of the church name Alla (1.6-2.0\%) and the former male Inna $(1.8-2.2 \%)$.

The second type of development - anthroponyms, sympathy for which decreases with decreasing age of informants - are represented by the namesfavorites Maria (3.1-2.9\%) and Kateryna (1.9-1.5\%), which, despite the regressive dynamics, did not leave the boundaries of the top ten favorites during all six age sections. The name Maria, first of all associated with the name of the Mother of God, who is the patron saint not only of the underprivileged, but also of the Zaporozhian army and the Ukrainian Insurgent Army, was sincerely loved by Ukrainians and has not lost its appeal since ancient times. "Almost until the Middle Ages, it could be heard

21 Півторак Г.П. 3 історії власних імен людей: Віталій, Мирон, Світлана. Культура слова. Київ : Наук. думка. 1985. Вип. 28. С. 54. 
only in the church. In writing, Maria first appears on scrolls of leather and papyrus of the sacred books: the Old and New Testaments, and others. It is there for women who have done something good and sublime ... "22; Kateryna is the "royal name" in the minds of most people, it became the name of the famous heroines of many Ukrainian songs and works of art.

Similar dynamics is demonstrated by the ancient church names of Ganna $(1.6-1.3 \%)$ - the name of the daughter of Yaroslav the Wise, wife of King Henry I of France - Anna Yaroslavna (c. 1030 - c. 1075), its popularity is also facilitated by the widespread use and in unofficial forms: "The sum of all variants of the name Ganna in modern Ukrainian dialects of Transcarpathia exceeds 70 "23; Valentina (1.7-1.5\%) - female form of male Valentine; beautiful name of ancient Greek origin Halyna (1.8-1.4\%); Nadiya (1.7-1.5\%), Liubov (1.2-1.0\%), Vira (1.3-1.1\%) - the names of the daughters of the great martyr Sophia; Nina (1.4-1.0\%) - "Georgian name", Nina - the name of the legendary founder of the Assyrian state; pleasant and melodious Lidia (0.6-0.5\%); female forms of male names Olexandra (0.8$0.6 \%)$, Evgenia (0.5-0.3\%), Daria (0.7-0.2\%); ancient church onyms Zinaida (0.4-0.2\%), Raisa (0.4-0.3\%), Tamara (0.8-0.5\%), Evdokia (0.2$0.02 \%)$ and the name of the legendary great martyr Sofia $(0.5-0.3 \%)$.

The best names that did not lose the position of leader during all age sections in the top ten, the ancient Greek Olena (3.6-3.5\%) and the canonized name of Princess Olha of Kiev (3.5-3.6\%), borrowed from Scandinavia, where Helga - "holy" and is a female form of the male name Oleh, demonstrate the third type of development, characterized by the same, equal treatment of the elderly and young. Names such as representatives of II-V age groups are taken more seriously.

And now we compare the attitude to the most favorite names of our respondents and the names of the most popular top ten real names (according to L.P. Zaichikova ${ }^{24}$, T.D. Bratushenko ${ }^{25}$ and O.Y. Karpenko ${ }^{26}$. (See table 4)

\footnotetext{
${ }^{22}$ Глинський І. Твоє ім'я - твій друг. Київ: Веселка,1985. С. 152.

23 Чучка П.П. Антропонімія Закарпаття. (Вступ та імена). Конспект лекцій. Ужгород, 1970. С. 23.

24 Зайчикова Л.П. Русский именник г.Одессы : Дис. ...канд.филол.наук. Приложение. Одесса, 1986. С. 71.

25 Братушенко Т.Д. Антропоніми Правобережного Побужжя. Украӥнське мовознавство. Київ : Вища школа. 1980. Вип. 8. С. 102.

${ }^{26}$ Карпенко Ю.А. Наиболее употребительные женские имена (на материале русских островных говоров Южной Украины). Русская ономастика: Сб. научн. тр. Одесса, 1984. С. 65.
} 
Table 4

Modern anthroponymic preferences and real naming (female names)

\begin{tabular}{|c|c|c|c|c|}
\hline \multirow{2}{*}{ № } & \multirow{2}{*}{$\begin{array}{c}\text { Favorite names on } \\
\text { the VI age section }\end{array}$} & Odesa & $\begin{array}{c}\text { Real name } \\
\text { Mykolayiv } \\
\text { region }\end{array}$ & $\begin{array}{c}\text { South } \\
\text { Of Ukraine }\end{array}$ \\
\hline 1 & Olha & Olena & Tetiana & Olena \\
\hline 2 & Olena & Natalia & Natalia & Tetiana \\
\hline 3 & Natalia & Iryna & Olena & Natalia \\
\hline 4 & Iryna & Tatiana & Oksana & Svitlana \\
\hline 5 & Tetiana & Olha & Liudmila & Oksana \\
\hline 6 & Maria & Svitlana & Iryna & Iryna \\
\hline 7 & Liudmila & Victoria & Larysa & Olha \\
\hline 8 & Svitlana & Halyna & Svitlana & Liudmila \\
\hline 9 & Oksana & Oksana & Olha & Larisa \\
\hline 10 & Victoria & Larisa & Inna & Victoria \\
\hline
\end{tabular}

Anthroponyms Ganna, Iryna, Maria, Olena, which during the twentieth century showed high activity in the real name of Uzhgorod ${ }^{27}$ did not leave the limits of the frequency ten in almost all age sections.

As can be seen from the table, almost all the favorite names of our respondents turned out to be fashionable in modern real naming, which allows us to predict their future dynamics. We observed a similar picture with regard to the male repertoire.

The change in relation to the rest of the popular names, which are below the top ten, was more pronounced (compare with the real noun of Odesa ${ }^{28}$ (63.71)). Much more often among modern anthroponymic preferences there are new names, the vast majority of which have a poetic color - Liliya (real name $-0.6 \%$, modern preferences $-1.8 \%)$, Alina $(0.1-0.8 \%)$, Valeria (0.4-1.0\%), Maya (0.1-0.6\%), Lina (0.1-0.4\%), Karina (0.1-0.4\%), Snizhana (0.1-0.5\%), Jana (0.3-0.6\%). But do not forget contemporaries and old names, mentioning them more often than they were registered in the real noun - Nadiya (0.2-2.0\%), Anastasia (0.2-1.6\%), Vira (0.2-1), 2\%), Lidia (0.2-1.0\%), Raisa (0.2-0.4\%), Margarita (0.4-0.7\%).

Thus, we found that the discrepancy between modern preferences and the picture of real naming actually affected only the names below the frequency ten. The popularity of a dozen favorite names has remained almost intact (with the exception of one name - Maria, sympathy for which has grown significantly, which gives hope for more frequent use and more.

${ }^{27}$ Шоля I.C. Динаміка частотного десятка жіночих імен Ужгорода впродовж XX ст. Записки з ономастики: зб.наук. пр. Одеса, 2019. Вип. 22. С. 141.

28 Зайчикова Л.П. Русский именник г. Одессы : Дис. ... канд. филол. наук. Приложение. Одесса, 1986. С. 71. 


\section{CONCLUSIONS}

1. The study of modern anthroponymic preferences of people of different ages, based on the materials of questionnaires, revealed a number of anthroponymic patterns and features. Personal names of Ukrainians constitute a stable, nationally characteristic fund of units.

2. When assessing the name as the best, respondents of different ages are guided by two main factors: social and psychological, but also takes into account a purely linguistic factor. The survey method provided a lot of additional information about names, to find out what people think about them.

3. The male names we have collected are a numerous complex containing pre-Christian, Christian and new names. Most of them in the materials of each slice show a different degree of activity. To a lesser extent, this applies to the traditional favorite names Serhiy, Oleksandr, Mykola, Volodymyr, Andriy, who topped the favorite lists for six sections. The degree of attractiveness of each name is determined primarily by tradition, household and literary prevalence.

4. The women's repertoire was more vivid than the men's. In both the masculine and the feminine, the temporal changes are more pronounced in relation to the names below the top ten. The names Olena, Olha, Iryna, Maria, Natalia, Tetiana, Liudmila became the most favorite for all our respondents. The contingent of women's sympathies, as well as men's, is staffed with various names such as pre-Christian, Christian and new name fund.

5. As the age of the respondents decreases, the composition of anthroponymic sympathies changes. The differences in the tastes of the elderly and young people are especially noticeable. Obviously, the formation of anthroponymic tastes of the younger generation was largely influenced by democratization in the choice of names. The spread of such names with progressive dynamics is associated with socio-cultural processes and aesthetic tastes. The elderly, on the contrary, defending antiquity, prefer the old calendar names.

6 . The motives for choosing the name as the best in our materials were different. Not all the information hidden in the name affects the commitment to it, because not all the information of the name is available to recipients. The main factor influencing the degree of popularity of the most commonly used names is the tradition, which in some way is influenced by fashion. The decline in sympathy for the names may be caused by its negative connotations. The degree of attractiveness of the name is also influenced by phonosymbolism, the phonetic form of the anthroponym.

7. Comparing modern anthroponymic tastes with real nouns during the twentieth century, we noticed a very clear distance between the frequency distribution of the noun of each age slice and the modern preferences of the bearers of this noun only in relation to peripheral names. The attitude to the names included in the group of popular, was almost the same. This comparison gives an idea of the actual use of the names in the future. 


\section{SUMMARY}

The article is devoted to the linguistic interpretation of one of the main classes of anthroponyms - personal names which function in the colloquial speech of Ukrainians in the Odesa region. Anthroponyms are studied from a sociolinguistic point of view: not really used names are analyzed, but those that are liked by people and subjectively assessed as the best. The source of the factual material was the materials of the sociolinguistic practice of students of the philological faculty of Odesa I.I. Mechnikov University. Each participant in the practice collected from the respondents' data on the names that they like the most. Both the official names and their folk colloquial variants were recorded. This article focuses on popular names, analyzes changes in attitudes towards them over time, and provides a comparative characteristic of modern anthroponymic preferences and a picture of real name use. The study found that views on popular names do not change significantly over time. The old church calendar anthroponyms became the favorite names. More expressive discrepancy in preferences is observed in the composition of peripheral names. It was revealed that the dominant criterion when choosing a name as the best is tradition, which is also influenced in a certain way by fashion. The results of a comparison of studies of contemporary anthroponymic preferences and the actual use of names make it possible to predict their future dynamics.

\section{REFERENCES}

1. Брайченко С.Л. Антропонімічні уподобання мешканців Одеської області України: лінгвістичний аналіз : Автореф. дис. ... канд. філол. наук. Одеса, 1999. С. 2.

2. Сенів M.I. До історії адаптації жіночих календарних імен в українській мові XIV - поч. XIX ст. Мовознавство. 1982. С. 72.

3. Кестра Р.Й. Українська антропонімія XVI ст. Чоловічі іменування. Київ : Наукова думка, 1984. С. 3.

4. Тихонов А.Н. Словарь русских личных имен. Москва : Школапресс,1995. С. 30.

5. Півторак Г.П. 3 історії власних імен людей: Віталій, Мирон, Світлана. Культура слова. Київ : Наукова думка. 1985. Вип.28. С. 53.

6. Півторак Г.П. 3 історії власних імен людей: Валентин, Валентина, Валерій. Культура слова. Київ : Наукова думка. 1985. Вип. 29. С. 50.

7. Глинський І. Твоє ім'я - твій друг. Київ : Веселка,1985. С. 109.

8. Скрипник Л.Г., Дзятківська Н.П .Власні імена людей: Словникдовідник / За ред. В.М. Русанівського. Київ : Наукова думка,1996. С. 44.

9. Коваль А.П. Практична стилістика української мови. Київ: Вища школа, 1987. С. 121.

10.Белей Л.О. Ім'я дитини в українській родині. Ужгород : Просвіта, 1993. С. 14. 
11. Демчук М.О. Слов'янські автохтонні особові власні імена в побуті українців XIV-XVII ст. Київ : Наукова думка, 1988. С. 39.

12. Коваль А.П. Життя і пригоди імен. Київ : Вища школа, 1988. C. 90.

13. Демчук М.О. Слов'янські автохтонні особові власні імена в побуті українців XIV-XVII ст. Київ : Наукова думка, 1988. С. 85.

14. Никонов В.А. Ищем имя. Москва : Сов.Россия, 1998. С. 104.

15. Півторак Г.П. 3 історії власних імен людей: Григорій, Дмитро, Святослав, Лідія, Ніла, Юлія. Украӥнська мова та література в школі. Київ : Наукова думка. 1986. № 10. С. 64.

16. Петрова Р.В. Динамика мужского именника г. Херсона. VI Pecn. ономаст. Конференція: Тези доп. I повід. Одеса, 1990. Ч. 2. С. 74.

17. Братушенко Т.Д. Антропоніми Правобережного Побужжя. Українське мовознавство. Київ : Вища школа. 1980. Вип. 8. С. 101.

18. Шоля I.C. Динаміка частотного десятка чоловічих імен Ужгорода впродовж XX ст. Записки з ономастики: збірник наукових праць. Одеса, 2017. Вип. 20. С. 264.

19. Зайчикова Л.П. Русский именник г. Одессы : дис. ...канд. филол. наук. Приложение. Одесса, 1986. С. 36-38.

20. Суперанская А.В. Имя и эпоха. Историческая ономастика: Сб ст. Москва : Наука, 1977. С. 15.

21. Глинський І. Твоє ім'я - твій друг. Київ : Веселка, 1985. С. 152.

22. Чучка П.П. Антропонімія Закарпаття. (Вступ та імена). Конспект лекцій. Ужгород, 1970. С. 23.

23. Зайчикова Л.П. Русский именник г. Одессы : дис. ...канд. филол. наук. Приложение. Одесса, 1986. С. 71.

24. Братушенко Т.Д. Антропоніми Правобережного Побужжя. Українське мовознавство. Київ : Вища школа. 1980. Вип.8. С. 102.

25. Карпенко Ю.А. Наиболее употребительные женские имена (на материале русских островных говоров Южной Украины). Русская ономастика: Сборник научных трудов. Одесса, 1984. С. 65.

\section{Information about the author:} Braychenko S. L., Candidate of Philological Sciences, Associate Professor at the Department of Information Activities and Media Communications

Odesa National Polytechnic University 1, Shevchenko Avenue, Odesa, 65044, Ukraine 